\title{
THE ROLE OF ELECTROMYOGRAPHIC BLINK REFLEX IN THE EVALUATION OF HEADACHE INCIDENCE
}

\author{
Marijan Cesarik ${ }^{1}$, Iris Zavoreo ${ }^{2}$, Lucija Zadro-Matovina ${ }^{2}$,Tomislav Madžar ${ }^{3}$ and Vanja Bašić Kes ${ }^{2}$ \\ ${ }^{1}$ Neurology Department, Požega General Hospital, Požega; ${ }^{2}$ Clinical Department of Neurology, \\ Sestre milosrdnice University Hospital Center; ${ }^{3}$ University of Zagreb, School of Medicine, Zagreb, Croatia
}

\begin{abstract}
SUMMARY - Migraine and tension type headache are the most common disabling primary headache disorders. Epidemiological studies have documented their high prevalence and high socioeconomic and personal impacts. According to recent data, migraine ranks as the third most prevalent disorder and seventh-highest specific cause of disability worldwide. Tension-type headache has lifetime prevalence in the general population ranging between $30 \%$ and $78 \%$ in different studies. According to the International Classification of Headache Disorders, $3^{\text {rd }}$ edition, there also are many other headaches but their incidence in general population is lower than the previously mentioned headaches. Trigeminal nerve and upper cervical segments $(\mathrm{C} 1-\mathrm{C} 3)$ are included in pain control of the head region and often evaluated in headache studies in order to improve differential diagnosis and headache treatment. In our study, we evaluated the potential role of electromyographic (EMG) blink reflex in establishing diagnosis of headache and evaluation of trigeminal nerve dysfunction as the possible underlying pathomorphological headache mechanism. Our study included 60 patients with different types of primary headaches and 30 control subjects. Statistical analysis was performed by use of $\chi^{2}$-test and statistical significance was set at $\mathrm{p}<0.001$. Study results showed that patients with trigeminal dysfunction in EMG blink reflex had a 5.6-fold higher risk of developing headache in comparison to subjects with normal EMG blink reflex finding.
\end{abstract}

Key words: Headache - diagnosis; Migraine disorders - diagnosis; Blinking; Electromyography; Predictive value of tests

\section{Introduction}

Migraine and tension type headache (TTH) are the most common disabling primary headache disorders. Epidemiologic studies have documented their high prevalence and high socioeconomic and personal impacts. According to recent data, migraine ranks as the third most prevalent disorder and seventh-highest specific cause of disability worldwide. Tension-type headache has lifetime prevalence in the general population ranging between $30 \%$ and $78 \%$ in different studies. According to the International Classification

Correspondence to: Assist. Prof. Iris Zavoreo, $M D, P h D$, Clinical Department of Neurology, Sestre milosrdnice University Hospital Center, Vinogradska c. 29, HR-10000 Zagreb, Croatia

E-mail: iris_zavoreo@yahoo.com

Received July 14, 2016, accepted August 9, 2016 of Headache Disorders, $3^{\text {rd }}$ edition, there also are many other headaches but their incidence in general population is lower than the previously mentioned headaches $^{1}$.

While it is highly doubtful that there is a significant sterile inflammatory response in the dura mater during migraine, it is clear that some form of sensitization takes place during migraine. Sensitization in migraine may have a peripheral component with local release of inflammatory markers, which would certainly activate trigeminal nociceptors, although a peripheral component is not necessary to explain the symptoms. More likely in migraine, there is a form of central sensitization that may be classical central sensitization, or a form of dysinhibitory sensitization with dysfunction of descending modulatory pathways. It is widely accepted that excessive muscle activity in peri- 
cranial muscles is of great importance for the development of TTH, as reflected in the term of muscle contraction headache. Nociceptive processes in craniofacial muscles are believed to play a role in the development and maintenance of TTH. In recent years, however, central mechanisms (sensitization of neurons in the central nervous system) have been favored ${ }^{2-4}$.

Trigeminocervical complex (TCC) includes the pseudounipolar trigeminal ganglion that has central afferent projections to the trigeminal nucleus caudalis in the medullary spinal cord, and a peripheral projection, largely from the ophthalmic division of the trigeminal ganglion, which innervates the cranial blood vessels and other cranial structures, including the painsensitive dura mater, via meningeal nociceptors. In animal models, it has been demonstrated that the central afferent projection to the trigeminal nucleus, using stimulation of the dura mater, also extends to the $\mathrm{C} 2$ and $\mathrm{C} 3$ regions of the cervical spinal cord. The TCC also receives inputs from the greater occipital nerve that converge with inputs from the dura mater. It is thought that anatomical transition from the trigeminal nucleus to the cervical spinal cord represents a functional continuum ${ }^{5,6}$.

It is known that the TCC is a key relay center for conveying sensory and visceral information, particularly nociceptive, from the head and orofacial region, including cranial vasculature, to higher pain processing centers in the brain, along the trigeminohypothalamic tract to the hypothalamus and trigeminothalamic (or quintothalamic) tract to the thalamus.

The blink reflex, also known as the orbicularis oculi reflex test, may be indicative of lesions or dysfunctions of the brainstem, and particularly assesses the trigeminal-facial arch. This reflex is elicited by stimulation of the supraorbital nerve on one side of the face, leading to two ipsilateral responses (R1 and R2) and one contralateral response (R2c). R1 represents an oligosynaptic pathway involving the main sensory nucleus of the trigeminal nerve and the intermediate subnucleus of the facial nerve. The second response, R2, involves a pathway of descent to the spinal trigeminal tract. The contralateral response, $\mathrm{R} 2 \mathrm{c}$, reflects the crossing of the brainstem in the medulla and progresses through the reticular formation to elicit a response at the contralateral facial nucleus ${ }^{7-9}$.

The results obtained by testing the blink reflex in patients with headaches have been very heterogeneous.
A lack of habituation to pain stimulus can be observed in migraineurs but not in patients with cluster headache. Some authors detected alterations in the blink reflex during a migraine attack; others noticed alterations during the inter-attack period in migraine patients $^{10,11}$. The results have been contradictory in the evaluated population with episodic migraine, cluster headache, hypnic headache, TTH and cervicogenic headache. The aim of our study was to evaluate the potential role of electromyographic (EMG) blink reflex in establishing diagnosis of headache and evaluation of trigeminal nerve dysfunction as the possible underlying pathomorphological headache mechanism ${ }^{12-14}$.

\section{Patients and Methods}

Our study included 60 patients with different types of primary headaches and 30 control subjects without symptoms of primary headaches. Headache diagnosis was established according to the International Classification of Headache Disorders, $3^{\text {rd }}$ edition. In all patients, trigeminal and facial nerve function was evaluated by use of EMG blink reflex. EMG results were correlated with the diagnosis of headache. EMG blink reflex was performed according to the standardized procedure. Statistical analysis was performed by use of $\chi^{2}$-test and statistical significance was set at $\mathrm{p}<0.001$.

\section{Results}

In our study, we included 60 patients with headache and 30 control subjects. There was no statistically significant difference in mean age between the groups ( $42.9 \pm 12.99$ vs. $42.63 \pm 11.7$ years). In headache group, there were $27 \%$ of women and $73 \%$ of men, and in control group $37 \%$ of women and $63 \%$ of men (Table 1).

There was a statistically significant difference in the percentage of normal EMG blink reflex findings between the headache group and control group (41.67\% vs. 80.0\%). EMG reflex showed pathologic finding unilaterally in $33.33 \%$ of headache patients and $13.33 \%$ of control subjects, and pathologic finding bilaterally in $25 \%$ of headache patients and $6.67 \%$ of control subjects, yielding statistically significant differences in both cases (Table 2).

The probability that the patient with headache had a pathologic and normal EMG blink reflex was 58\% 
Table 1. Demographic data and results of EMG blink reflex in study population

\begin{tabular}{|l|l|l|}
\hline & Headache & Controls \\
\hline Number of patients & 60 & 30 \\
Mean age (years \pm SD) & $42.9 \pm 12.99$ & $42.63 \pm 11.7$ \\
Women/men (\%) & $27 / 73$ & $37 / 63$ \\
Normal finding & $41.67 \%$ & $80.0 \%$ \\
Pathologic changes unilaterally & $33.33 \%$ & $13.33 \%$ \\
Pathologic changes bilaterally & $25.0 \%$ & $6.67 \%$ \\
\hline
\end{tabular}

$\mathrm{EMG}=$ electromyography

Table 2. Number of patients with normal and pathologic EMG blink reflex finding in headache and control groups

\begin{tabular}{|l|l|l|l|}
\hline \multirow{2}{*}{} & \multicolumn{3}{|c|}{ Blink reflex } \\
\cline { 2 - 4 } & Normal & Pathologic & All \\
\hline Headache & 25 & 35 & 60 \\
Controls & 24 & 6 & 30 \\
All & 49 & 41 & 90 \\
\hline
\end{tabular}

$\mathrm{EMG}=$ electromyography

Table 3. Frequency of patients with normal versus pathologic EMG blink reflex finding according to the presence of headache symptoms

\begin{tabular}{|l|l|l|}
\hline \multirow{2}{*}{} & \multicolumn{2}{|c|}{ Blink reflex } \\
\cline { 2 - 3 } & Normal & Pathologic \\
\hline Headache & $25 / 60(0.42 \%)$ & $35 / 60(0.58 \%)$ \\
Controls & $24 / 30(0.80 \%)$ & $6 / 30(0.20 \%)$ \\
\hline
\end{tabular}

$\mathrm{EMG}=$ electromyography

and $42 \%$, respectively. If the patient had no symptoms of headache, there was $20 \%$ probability that the EMG blink reflex was pathologic and $80 \%$ probability that the EMG blink reflex was normal (Table 3).

In patients with normal EMG blink reflex finding, there was $51 \%$ probability that the symptoms of headache were present and $49 \%$ probability that the symptoms were not present. In patients with pathologic EMG blink reflex, there was $85 \%$ probability that the headache symptoms were present and $15 \%$ probability that the symptoms were not present. We demonstrated that patients with trigeminal dysfunction in EMG blink reflex had a 5.6-fold higher risk of developing headache in comparison to subjects with normal EMG blink reflex finding (Table 4).
Table 4. Frequency of headache according to pathologic versus normal EMG blink reflex finding

\begin{tabular}{|l|l|l|}
\hline \multirow{2}{*}{} & \multicolumn{2}{|c|}{ Blink reflex } \\
\cline { 2 - 3 } & Normal & Pathologic \\
\hline Headache & $25 / 49(0.51 \%)$ & $35 / 41(0.85 \%)$ \\
Controls & $24 / 30(0.49 \%)$ & $6 / 41(0.15 \%)$ \\
\hline
\end{tabular}

$\mathrm{EMG}=$ electromyography

\section{Discussion}

In neurological evaluation of patients with headache, it is always of great importance to find some biomarker that will confirm or exclude the diagnosis of headache. Unfortunately, diagnosis is still made according to patient history. The role of EMG blink reflex in the evaluation of different types of headache is still under investigation. In migraine patients, different authors have shown that changes of EMG blink reflex can be found in migraine attack, as well as in the interval between two attacks. In the studies evaluating other types of headache, results are very heterogeneous. In our study, $58 \%$ of patients with headache had changes in EMG blink reflex, unilaterally in 33.33\% and bilaterally in $25 \%$. In control subjects, the probability that the EMG blink reflex would be pathologic was $20 \%$, showing that there is subclinical dysfunction of the TCC ${ }^{11-14}$.

Previous studies have shown that patients with episodic migraine may present alterations in blink reflex, particularly regarding habituation to the stimulus, while TTH, cluster headache, cervicogenic headache and hypnic headache all presented negative or controversial information on the blink reflex responses. We showed that patients with trigeminal dysfunction in EMG blink reflex had a 5.6-fold higher risk of developing headache as compared to subjects with normal EMG blink reflex finding.

Once again, our study showed that there was dysfunction of the TCC in different types of headache, not only in migraine, and that changes in EMG blink reflex could predict an increased risk of developing headache in symptom-free persons. Further investigations should be performed in patients with different types of headache to evaluate the role of different central and peripheral components of blink reflex in correlation with clinical picture of headache, as well as reaction to therapeutic interventions. 


\section{References}

1. Headache Classification Committee of the International Headache Society (IHS). The International Classification of Headache Disorders, $3^{\text {rd }}$ edition (beta version). Cephalalgia. 2013;33(9):629-808. DOI: 10.1177/0333102413485658

2. Tajti J, Szok D, Párdutz A, et al. Where does a migraine attack originate? In the brainstem. J Neural Transm. 2012;119:55768. DOI: 10.1007/S00702-012-0788-9

3. Lipton RB. Chronic migraine, classification, differential diagnosis, and epidemiology. Headache. 2011;51(2):77-83. DOI: 10.1111/J.1526-4610.2011.01954.X

4. Bašić Kes V, Jurašić MJ, Zavoreo I, Ćorić L, Rotim K. Migraine, carotid stiffness and genetic polymorphism. Acta Clin Croat. 2015;54(4):409-16.

5. Overend W. Preliminary note on a new cranial reflex. Lancet. 1986;1:619. DOI:10.1590/0004-282X20130139

6. de Marinis M, Pujia A, Collaizo E, Accornero N. The blink reflex in chronic migraine. Clin Neurophysiol. 2007;118: 457-63. DOI: 10.1590/0004-282X20130139

7. Yildirim G, Sayin R, Cogen EE, Odabas FO, Tombul T. Randomised, controlled blink reflex in patients with migraine and tension type headache. J Pak Med Assoc. 2011;61:978-82.
8. Holle D, Gaul C, Krebs S, et al. Nociceptive blink reflex and pain related evoked potentials in hypnic headache. Cephalalgia. 2011;31:1181-8. DOI: 10.1177/0333102414535996

9. Bidin Brooks JB, Dadalti Fragoso Y. The blink reflex test does not show abnormalities in a large group of patients with chronic migraine. Arq Neuropsiquiatr. 2013;71(11):862-5. DOI: 10.1590/0004-282X20130139

10. Peddireddy A, Wang K, Svensson P, Arendt-Nielsen L. Blink reflexes in chronic tension-type headache patients and healthy controls. Clin Neurophysiol.2009;120:1711-6.DOI: 10.1016/j. clinph.2009.06.024

11. Holle D, Zillessen S, Gaul C, et al. Habituation of the nociceptive blink reflex in episodic and chronic cluster headache. Cephalalgia. 2012;32:998-1004.

12. Avramidis TG, Podikoglou DG, Anastasopoulos IE, Koutroumanidis MA, Papadimitriou AL. Blink reflex in migraine and tension-type headache. Headache. 1998;38:691-6.

13. de Tommaso M, Murasecco D, Libro G, et al. Modulation of trigeminal reflex excitability in migraine: effects of attention and habituation on the blink reflex. Int J Psychophysiol. 2002; 44:239-49.

14. Lisak M, Demarin V, Trkanjec Z, Zavoreo I, Bašić Kes V. Person-oriented perspectives in neurology. Acta Clin Croat. 2014; 53(4):423-9.

Sažetak

\section{ULOGA ELEKTROMIOGRAFSKOG REFLEKSA TREPTAJA U PROCJENI POJAVNOSTI GLAVOBOLJA}

\section{Cesarik, I. Zavoreo, L. Zadro-Matovina, T. Madžar i V. Bašić Kes}

Migrena i tenzijska glavobolja su dvije najčešće primarne glavobolje koje izazivaju ograničenja u svakodnevnom funkcioniranju. Epidemiološke studije su potvrdile njihov socioekonomski utjecaj i utjecaj na privatni život. Prema današnjim podacima, migrena je na trećem mjestu po učestalosti pojavljivanja te na sedmom mjestu po stupnju onesposobljenosti koju uzrokuje širom svijeta. Tenzijska glavobolja javlja se u općoj populaciji u 38\%-78\% osoba tijekom života. U skladu s najnovijom međunarodnom klasifikacijom glavobolja, The International Classification of Headache Disorders, 3. izdanje, postoji još čitav niz drugih primarnih glavobolja, no one imaju manju pojavnost nego ranije navedene glavobolje. Trodijelni živac i gornji segmenti vratne kralježnice (C1-C3) uključeni su u kontrolu boli u području glave i vrata te se njihova uloga često istraživala kako bi se poboljšala dijagnostika i liječenje glavobolja. U našem ispitivanju procjenjivali smo potencijalnu ulogu EMG refleksa treptaja u postavljanju dijagnoze glavobolje, kao i procjenu utjecaja disfunkcije trodijelnog živca kao patomorfološkog mehanizma u nastanku glavobolje. U studiju smo uključili 60 ispitanika s primarnom glavoboljom i 30 kontrolnih osoba. Statistička analiza je provedena pomoću $\chi^{2}$-testa, a statistička značajnost je bila $p<0,001$. Rezultati istraživanja su pokazali da disfunkcija trodijelnog živca dokazana EMG refleksom treptaja povećava rizik za razvoj glavobolje 5,6 puta u odnosu na ispitanike kod kojih je nalaz EMG refleksa treptaja uredan.

Ključne riječi: Glavobolja - dijagnostika; Migrenski poreméaji - dijagnostika; Elektromiografja; Treptanje; Prediktivna vrijednost testova 